\title{
Development of Science and Technology Parks in Poland: Opportunities for New Modes of Cooperation in the Biopharmaceutical Industry
}

\author{
Michał Staszków \\ Poznan University of Economics and Business, Poland \\ michal.staszkow@ue.poznan.pl \\ Łukasz Puślecki \\ Poznan University of Economics and Business, Poland \\ lukasz.puslecki@ue.poznan.pl \\ Piotr Trạpczyński \\ Poznan University of Economics and Business, Poland \\ Piotr.trapczynski@ue.poznan.pl
}

The aim of the article is to verify the development of science and technology parks in Poland as well as the opportunities of development of new forms of cooperation with the use of science and technology parks in the biopharmaceutical industry in Poland. The first section reviews the origins and definitions of science and technology parks in order to clarify and systematize the concepts used in existing research and practice. Subsequently, the ensuing sections discuss the evolution of science and technology parks and different organizational models of s т P s. Further, the analysis centres on science and technology parks in Poland. Then the importance of science and technology parks for the development of new modes of cooperation in the biopharmaceutical industry is elaborated upon. The paper ends with a set of implications and conclusions.

Key Words: biotechnological cluster, science and technology parks, open innovation, open innovation alliance

JEL Classification: 032, $\mathrm{O} 33$

https://doi.org/10.26493/1854-6935.15.23-41

\section{Introduction}

The ability to create and implement innovation contributes to creating a competitive advantage for businesses, regions and countries. In this context, innovative and entrepreneurial support centres should play an important role in fostering innovation in the economy. The authors of this paper focus on science and technology parks (s TPs), which in recent years have become a popular tool for implementing the innovation 
policy of the European Union and individual countries. Technological parks, apart from industrial clusters, are considered to be the most advanced and comprehensive institutional form of the knowledge economy (Felsenstein 1994; Asheim and Coenen 2005; Matusiak and Bąkowski, 2008). Technological parks, as a tool of innovation policy of countries and regions, are to contribute to increasing the level of innovation, both at the local and national level.

In the literature of economics, economic geography or public policy, there is no clearly defined theory concerning the formation of technology parks. Link and Scott (2007) found that the most similar theory, to which the phenomena of technological parks may relate, is the concept of industrial clusters. Thanks to the proximity of a technology park, it is possible to streamline knowledge across companies, research institutes and universities, thus fostering innovation. Moreover, technology parks are often trying to attract companies from specific, highly specialized industries, which is analogous to industrial clusters.

The aim of the article is to verify the development of science and technology parks in Poland as well as the opportunities of development of new forms of cooperation with the use of science and technology parks in the biopharmaceutical sector in Poland. The paper is structured as follows. The first section reviews the origins and definitions of science and technology parks in order to clarify and systematize the concepts used in existing research and practice. Subsequently, the ensuing sections discuss the evolution of science and technology parks and different organizational models of s TPS. Further, the analysis centres on science and technology parks in Poland. Then the importance of science and technology parks for the development of new modes of cooperation in the biopharmaceutical industry is elaborated upon. The paper ends with a set of implications and conclusions.

\section{Science, Research and Technology Parks: Origins and Definitions}

The first parks, as a tool of scientific policy and later innovation policy, appeared in the 1950s. In the literature of the subject, the first unit of this type is listed Bohanson Research Park in Menlo Park, California, founded in 1948 (Wessner 2009). Most researchers consider the first actual technology park, however, to be Stanford Research Park, which was established in 1951 at Stanford University. It was around this park that the socalled Silicon Valley, an area of innovation and high technology, flour- 
ished later on. One of the oldest parks in Europe is Cambridge Science Park, created in 1970 (http://www.cambridgesciencepark.co.uk), whole twenty years after the establishment of the Stanford Research Park.

For the first technology park in Poland should be recognized Poznan Science and Technology Park, founded on the initiative of the University of Adam Mickiewicz in Poznań in 1995 (Matusiak and Bąkowski 2008). In the 80's and 9o's of the 2oth century more and more units of this type began to appear, and research conducted cyclically by the International Association of Science Parks and Areas of Innovation (IASP) indicates that more than $50 \%$ of science and technology parks in the world were established after 2000 (IASP 2012). In the 80's and 90's of the 2oth century, cities brought to life institutes called technology parks to support the process of reindustrialisation, to contribute to regional development, and to create synergies between companies located within parks (Castells and Hall 1994). The specific fashion for creating technology parks in Europe after 2000 may be the result of European Union policies. Many units of this type, also in Poland, were created thanks to the availability of $\mathrm{EU}$ funds allocated for the construction of infrastructure, management or development of an innovative environment.

In the literature of the subject there are many names referring to the concept of technology park: science parks, technology, research, science and research, science and technology, industry, industry and technology (Link and Scott 2007; Pelle, Bober, and Lis 2008; Link 2009; World Bank 2010; Matusiak 2011). The IASP conducted a study among these units and presented the following results on the naming (Matusiak and Bąkowski 2008):

- technology park - $30 \%$ of all parks,

- science park - $24 \%$,

- science and technology park - 13\%,

- research park - 10\%,

- technopolis - 5\%,

- other $-18 \%$.

Differences in naming of parks result from cultural, legal and ownership differences. In Poland, the most commonly used name is technology park, in France technopolis, and in the United States research park, which is connected with the functioning of parks within the university or in its immediate vicinity. Their functions are convergent and focus on supporting innovation and entrepreneurship. 
IASP has created a technology park definition in 2002, according to which a technology park is an organization run by qualified professionals whose aim is to increase the well-being of the community in which it operates by promoting a culture of innovation and competition among knowledge-based entrepreneurs and institutions (IASP 2012). To achieve the above park objectives:

- Stimulates and manages the flow of knowledge and technology between higher education institutions, R\&D units, businesses and markets;

- Facilitates the creation and development of knowledge-based enterprises through incubation and budding;

- Adds value to companies through high-quality services and access to high-quality space and infrastructure (IASP 2012).

In the Polish legislation, there is also a definition of a technology park as a set of separated real estate with technical infrastructure, created to transfer knowledge and technology between scientific units and entrepreneurs, where entrepreneurs are offered modern technology services in the field of: consulting in the creation and development of enterprises. The transfer of technology and the transformation of research and development into technological innovation, as well as the creation of favourable business conditions by making available the real estate and technical infrastructure on a contractual basis ('Ustawa $\mathrm{z}$ dn. 20 marca' 2002).

The United Kingdom Science Parks Association (http://www.ukspa .org.uk) cites the following definition of a science park: A Science Park is a business support and technology transfer initiative that:

- Encourages and supports the start up and incubation of innovationled, high-growth, knowledge-based businesses.

- Provides an environment where larger and international businesses can develop specific and close interactions with a particular centre of knowledge creation for their mutual benefit.

- Has formal and operational links with centres of knowledge creation such as universities, higher education institutes and research organisations.

The Association of University Research Parks (http://www.aurp.net), operating in the United States, defines a university research park as a property-based venture, which:

- Master plans property designed for research and commercialization; 
TABLE 1 Main Features of Science and Technology Parks

\begin{tabular}{ll}
\hline Goal & Enhancing knowledge transfer from universities to business. \\
\hline Infrastructure & $\begin{array}{l}\text { High quality, low building construction ratio, coupled with a wide } \\
\text { range of business support services. }\end{array}$ \\
\hline Links & $\begin{array}{l}\text { University or a suitable R \& D centre must be formally committed to } \\
\text { collaborate with the science park and firms (normally, universities } \\
\text { should have an important role in the science parks management). }\end{array}$ \\
\hline Access & $\begin{array}{l}\text { Restricted to knowledge activities, with possible sectoral preferences } \\
\text { (if knowledge base is significant across different scientific fields and } \\
\text { there is entrepreneurial critical mass - not likely in many followers' } \\
\text { regions). }\end{array}$ \\
\hline
\end{tabular}

Notes Adapted from Almeida, Santos, and Silva $(2009,5)$.

- Creates partnerships with universities and research institutions;

- Encourages the growth of new companies;

- Translates technology;

- Drives technology-led economic development.

Regardless of naming, parks play a similar role - they stimulate the flow of knowledge and enable the development of entrepreneurship and innovation. The definitional differences result from ownership, legal and cultural determinants. The tasks and services of the park initiatives remain similar and their common features are shown in table 1.

Access to infrastructure, connections with scientific research units and developed organizational structures in an ideal, modelled situation allow realizing the following benefits (Matusiak 2008):

- Research institutions offering new technological solutions and innovative companies seeking new development opportunities;

- Rich business environment in the areas of finance, consulting, training and support for the development of innovative companies;

- Para-bank institutions financing high-risk ventures;

- High quality of infrastructure and environmental values;

- High entrepreneurial potential and business climate, attracting creative people from other regions;

- Government, regional and local programs to support entrepreneurship, technology transfer and the development of new technology companies.

The combination of the aforementioned elements is intended to enable specific objectives to be set before technology parks, namely: 
- Incubation of start-up companies - supporting entrepreneurship in general as well as high technology companies is one of the core tasks of technology parks. Typically, incubated companies receive an offer to rent space on preferential terms. Support also covers training, management, legal and accounting services.

- Business services - this service includes advice on business start-up and registration, business plan development, and fundraising. The service is not limited to incubation companies, it is available both to park tenants and outside companies.

- Leasing of office, production, and laboratory and production space - the area may be offered to companies located at the end of the incubation process within the park as well as to outside companies.

- Research services - this applies to services provided by laboratories located in the park.

- Technology transfer services - this is also one of the fundamental objectives of the operation of technology parks. Technology transfer between enterprises and $\mathrm{R} \& \mathrm{D}$ units is carried out when the park can provide specialist services such as innovative project management, marketing services, market research.

- Management of investment areas - some of the parks have the investment space they use for developing businesses.

- Training and education - this is a key issue for incubated businesses and a form of support for existing companies. These companies are often just learning how to operate in the market, so training in running a business, raising capital or marketing is beneficial to them (Matusiak and Bąkowski 2008).

These goals are universal, regardless of the name, legal form or function model adopted by the individual. Over the past 60 years of existence, the concept of technology parks has changed, and the above objectives relate mainly to the so-called parks. In this work, the name for the concept of science, technology, research parks is the technology park, which is the most frequently used name in Poland.

\section{Evolution of Science and Technology Parks}

Similar to the case of science and innovation policy, the concept and functions of technology parks have evolved. The literature on the subject lists three generations of technology parks. First-generation science 
parks, created in the 1950 and 8 os, were aimed at reindustrialisation, industrial development and the transfer of knowledge. Creation of innovative products was treated as an additional function but not as a significant effect of park tenants' activity (Staszków 2013). The parks in those years were located in or near the university campus, while they were mainly established by the university. They decided to set up parks because they wanted to earn money on unused areas of university buildings. Space rental offer was adapted over the years to the needs of new companies that were no longer subject to the reindustrialisation process. The offer was broadened to research laboratories and other specialized facilities, as well as equipment that enabled companies to create new technologies. At the same time universities, seeing the potential inherent in the concept of science parks, turned their attention to the more commercial use of research, often in cooperation with technology park tenants. Consciously created first generation turned out to be a great success. The best example of this statement is Stanford Research Park, which was initiated by Dr. Ted Terman (Matusiak 2011). During his studies at the Massachusetts Institute of Technology, Terman saw the independent concentration of innovative companies around the university. When he became the chancellor at the Stanford University, he had to cope with the financial problems of the university. He designated an industrial zone for small and medium-sized businesses. Thanks to that, the technology park was established, around which the Silicon Valley was founded with its most innovative companies, including Apple, Intel or A M D.

The success of the first parks caught the attention of public authorities, who began to think of technology parks as a tool of innovation policy. Such approach led to the creation of second-generation parks, mainly in the 1990s. Second generation technology parks, in addition to their existing infrastructure functions, provide broadly defined business services, targeted at the development of innovative companies from specific industries, including I T, biotechnology, and medicine. At first, the concentration on the specific industry was the result of the specialization of the 'parent' university, but with time, the politicians came to the floor. Recognizing certain industries as more forward-looking and more profitable, politicians decided to create specialized science and technology parks, and from this time not only at the universities (Henneberry 1984). This is one of the key points in the evolution of the concept of parks universities have been ceased to be crucial and parks can be established by commercial companies. The specialization of the park activity brings 


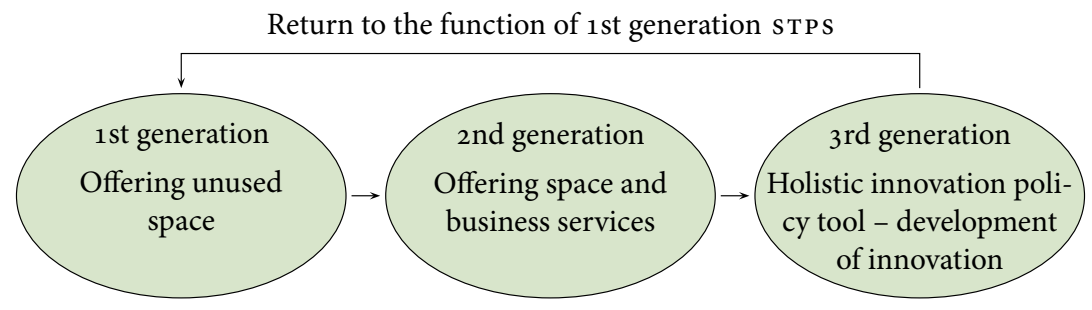

FIgURE 1 Changes in Technology Parks' Functions in Particular Generations

many benefits, such as the concentration of companies in a given industry in one place, which facilitates the flow of knowledge and enables cooperation. Next advantage is the adaptation of the park offer to the needs of a specific group of customers. Another feature of second-generation science parks was their incubation function. Efforts have been made to allow students and graduates to develop their businesses through financial and management support, which is crucial in the early stages of business. Business incubation was possible thanks to the public subsidies. Critics of the concept of parks emphasize that such subsidies weaken the mechanism of market regulation (Pelle, Bober, and Lis 2009). Some of the technology parks have been probably created only because the funding was available, but on the same time, the main objectives of the science park concept went down. As a result, some of the park initiatives, after the $\mathrm{EU}$ project is finished, may return to the function of first generation parks, i.e. to offer commercial space for businesses on a regular basis (figure 1). This applies to both second and third generation parks.

Third generation parks are designed to implement innovation policy objectives. They are a part, a tool of regional and national innovation systems. It is emphasized that parks are a tool that will contribute to the increase of the level of innovation and the competitiveness of the economy. They are also intended to help in implementing the Europe 2020 Strategy. As far as functions are concerned, the incubation activity has been complemented by the networking role. Second-generation parks, due to the intensive development of commercial units of this type, have reduced the role of universities. Third-generation parks strongly underline the role of universities in creating knowledge and innovation. Building relationships between park tenants and universities is one of the most important tasks facing the parks.

They are also considered the place where science connects to business, students as well as researchers can realize their ideas through the sup- 
TABLE 2 Evolution of Science Parks over Time

\begin{tabular}{|c|c|c|}
\hline $1950-1980$ & $1990 \mathrm{~s}$ & 2000 and beyond \\
\hline $\begin{array}{l}\text { - Real-estate operations } \\
\text { - Campus-like environ- } \\
\text { ment, selling single } \\
\text { parcels of land } \\
\text { - Focus on industrial } \\
\text { recruitment } \\
\text { - Few, if any, ties be- } \\
\text { tween tenants and } \\
\text { university or federal } \\
\text { laboratories } \\
\text { - Little business assis- } \\
\text { tance and few services } \\
\text { provided }\end{array}$ & $\begin{array}{l}\text { - Anchor with R\&D } \\
\text { facilities aligned with } \\
\text { industry focus of park } \\
\text { - Innovation centres and } \\
\text { technology incubators } \\
\text { more common } \\
\text { - Multitenant facilities } \\
\text { constructed to ac- } \\
\text { commodate smaller } \\
\text { companies } \\
\text { - Some support for } \\
\text { entrepreneurs and } \\
\text { start-up companies } \\
\text { provided directly }\end{array}$ & $\begin{array}{l}\text { - More and more mixed-use } \\
\text { development, including com- } \\
\text { mercial and residential } \\
\text { - Increased focus and deeper } \\
\text { service support to start-ups } \\
\text { and entrepreneurs } \\
\text { - Less focus on recruitment } \\
\text { - formal accelerator space and } \\
\text { plans for technology commer- } \\
\text { cialization roles emerging } \\
\text { - Greater interest on part of } \\
\text { tenant firms in partnering with } \\
\text { universities } \\
\text { - Universities more committed } \\
\text { to partnering with research } \\
\text { park tenants } \\
\text { - Amenities from day care to } \\
\text { conference and recreational } \\
\text { facilities added }\end{array}$ \\
\hline
\end{tabular}

NOTES Adapted from World Bank (2010).

port and experience of the university, on the one hand, and the capital of private entrepreneurs located in the park on the other hand. The most important features and functions of technology parks in the three stages of the park concept evolution are presented in table 2.

At present, the parks, both mature and in the early stages of development, are assumed to be third generation parks. This is primarily due to the functions to which they were appointed, and to the assumptions of the innovation policy of which they are part. In this paper, the described aspects also apply to third generation parks.

\section{Different Organizational Models of STP S}

Professor John Allen, a long-time director of Manchester Science Park and a two-time UKSPA president, has identified four models defining the formation of technology parks, which to some extent determine the nature of the unit (Allen 2007):

- alliance-driven,

- university-driven,

- company-driven, and 
TABLE 3 Four Models of Creation of stps' and Their Main Features

\begin{tabular}{ll}
\hline Model & Main features \\
\hline Partners & - Partners - two or more partners (both public and private) work together \\
& to develop a technology park. \\
- The common goal is an economic development based on knowledge & transfer and innovation development. \\
- Public funding enables park construction and infrastructure develop- & ment. \\
- A separate organization is established that manages the park develops, & develops and implements strategic objectives. \\
\hline University & Technology park operates within a university campus, the university \\
& owns land or infrastructure, thus earning revenue. \\
- A significant portion (usually over 40\%) of tenants are spin-off or start- & up companies, also founded by students and university graduates. \\
- A large number of researchers are involved in the activities of park ten- & ants, as directors, mentors, partners, etc. \\
• Entrepreneurship and management are an important part of university \\
study programs. \\
- Incubation service for spin-off companies operating in the local envi- \\
ronment is offered.
\end{tabular}

Continued on the next page

- cluster-driven.

The models mentioned above are primarily related to the park's stakeholders. It is also the most common cause of differences in naming and defining technology parks. The characteristics of each model are shown in table 3 .

The most commonly used model in Poland is the partnership approach in which the decision to launch a park is undertaken by public bodies. Examples of parks operating on the basis of partnership approach are Technopark Gliwice (the founder were the Gliwice city, Silesian University of Technology and Katowice Special Economic Zone), Lodz Regional Science and Technology Park (Łódź City and Marshal's Office, as well as three biggest public universities: Lodz University of Technology, Lodz University and Medical University, and representatives of business: Lodz Chamber of Commerce and Industry), Torun Technology Park (regional and local authorities and Nicolaus Copernicus University in Toruń). In all of the above examples, the founders are also higher education institutions, but in this case, we cannot talk about the university model, as the main initiators and stakeholders are local government units. Furthermore, the parks are not located in or near an academic campus. An ex- 
TAB LE 3 Continued from the previous page

Corporate - Anchor tenant, usually a firm with a well established market position,
occupies the majority of the park property.
- The presence of a large player attracts other tenants, including the par-
ticipants of the main tenant supply chain.
- In the contacts between the main tenant and other tenants, the open
innovation model is used.
- In the case of a university affiliation, the principal tenant has a strong in-
- fluence on research, often involving products or services that he creates.
- The university also adapts the program to the specific characteristics of
the principal tenant's activities, enabling graduates to find work in one of
the companies located within the park.
- The park is made up of a group of companies from a given sector, close
to the geographical distance.
- This type of partnership is designed to provide a service tailored to the
needs of the group members.
- The links to knowledge builders are created by the demands of compa-
nies, and are not forced by government policy or university specializa-
tion.
- There is no single landowner or infrastructure owner.
- This is a concept that supports economic development through the
creation of science cities.

NOTES Authors' elaboration based on Allen (2007).

ample of a park operating based on a university model is the Poznan Science and Technology Park, which is the first technology park in Poland, and was founded as the initiative of the Adam Mickiewicz University in Poznan. The managing body is the Foundation of Adam Mickiewicz University in Poznan. The current president of the foundation and director of the park is Professor Jacek Guliński. The park authorities also have other university researchers, which is consistent with the characteristics of the university park approach described above. The incubation function is strongly developed, which focuses on economic activity of students, postgraduates and graduates, as well as academics, mainly from high technology industries such as biotechnology and IT. The university model is most common in the United States and the United Kingdom. This is due to the previously mentioned stages of the evolution of the parks that were originally established within the universities.

\section{Science and Technology Parks in Poland}

The first technological park in Poland was the Poznań Science and Technology Park, founded in 1995 on the initiative of the Adam Mickiewicz 
FIGURE 2

Location of Science and Technology Parks in Poland (authors' elaboration based on Bąkowski and Mażewska 2015)

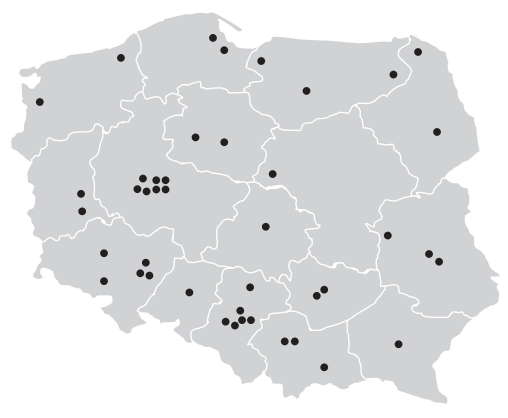

University. According to the Association of Organizers of Innovation and Entrepreneurship Centers (sooIPP), which are considered equivalent to AURP or IASP, there are currently 42 technology parks in Poland. sooipp also conducts cyclical research on technology parks and other Innovation Support Centres in Poland. The last study was held in 2014 and the data contained in this section are taken from the report, edited by Aleksander Bąkowski and Marzena Mażewska (2015).

Until 200o, only $9 \%$ of the 42 identified technology parks were created in Poland. $36 \%$ were appointed in 2001-2005, another $33 \%$ in 2006-2010, $21 \%$ in 2011-2014. The noticeable decrease in the emergence of parks is due to the limited resources available from European funds for this purpose. Some of the initiatives in previous years have been suspended, three parks have not started, and two have been liquidated. There are many reasons for this - first and foremost, the misidentified need to locate the park at a given location, the lack of demand for technology parks, the failure to tailor the service portfolio to potential clients, and, for example, the incorrect management of the park.

Parks are located in all voivodships; their location is shown in figure 2. The layout of technology parks is not uniform; six units of this type are located in the Wielkopolska Region and Ślaskie voivodeships, five in the Lower Silesian voivodeship, in other voivodships there are one to three parks. The fact that there are six technology parks in Wielkopolska does not affect the development of the entire region, as they are located in or around Poznań itself. In Poznań, or close neighbourhood, there are:

- Poznań Science and Technology Park of the Foundation of the Adam Mickiewicz University;

- Nickel Technology Park Poznan (YouNick) - a park located in Złotniki near Poznań, it is the first non-public technology park in Poland; 
TABLE 4 Infrastructural Potential of Technology Parks in Poland

\begin{tabular}{lr}
\hline Usable area of buildings at the disposal of the institution in total $\left(\mathrm{m}^{2}\right)$ & 373654 \\
Office space for own use $\left(\mathrm{m}^{2}\right)$ & 22001 \\
Usable area for rent $\left(\mathrm{m}^{2}\right)$ & 154490 \\
Own laboratory surface $\left(\mathrm{m}^{2}\right)$ & 14090 \\
Laboratory space for rent $\left(\mathrm{m}^{2}\right)$ & 20383 \\
\hline Didactics/seminar rooms (number) & 129 \\
Meeting rooms (number) & 92 \\
Computer laboratories (number) & 18 \\
\hline
\end{tabular}

Notes Adapted from Bąkowski and Mażewska (2015).

- Eureka Technology Park in Dąbrówka near Poznań;

- Poznań Industrial and Technological Park, where the main shareholder is the city of Poznań;

- Noble Tower Technology Center;

- Luvena Technology Park in Luboń.

Such a high concentration of technology parks in one place is unfavourable and may contribute to lowering the efficiency of the operation. High competition means that parks want to fill free spaces do not use specialization, accepting tenants from each industry. Some of the parks have no formal connection with the university, only Poznań Science and Technology Park operates in conjunction with the Adam Mickiewicz University, and Poznań Industrial Technology Park works in agreement with Poznań University of Technology.

Most parks in Poland operate based on an integrated model, which determines their ownership structure. $52 \%$ of parks operate as a limited liability company, $24 \%$ operate as a joint stock company, $19 \%$ as a budgetary unit, $2 \%$ as a foundation, $2 \%$ within the university. However, the links with the university are noticeable because the equity in the parcels are covered by 18 universities, similarly as with the IASP data, information on the volume of shares is not available.

The infrastructure of the Polish technology parks is well developed, mainly thanks to funds obtained from $\mathrm{EU}$. Offices are tailored to the latest trends that foster creativity and knowledge flow. Twelve parks also have laboratories adapted for biotechnological research. The infrastructural potential of Polish parks is presented in table 4 .

The scope of services provided to park tenants coincides with the port- 
TABLE 5 Services Offered by Polish Technology Parks (\%)

\begin{tabular}{|c|c|c|}
\hline Service & 2011 & 2013 \\
\hline Help with contacting the technology vendor or customer & 32 & 50 \\
\hline Consultation and selection of innovative ideas & - & 44 \\
\hline Prepare a bid or ask for technology & 18 & 36 \\
\hline Collaboration abroad - internationalization & - & 36 \\
\hline $\begin{array}{l}\text { Market analysis and definition of market potential and technical } \\
\text { development possibilities of the idea }\end{array}$ & - & 36 \\
\hline $\begin{array}{l}\text { Consultancy on the protection of intellectual property rights } \\
\text { for companies }\end{array}$ & 45 & 33 \\
\hline Advisory support in technology deployment & 32 & 28 \\
\hline Technological audit & - & 28 \\
\hline Develop a plan for implementing an innovative solution & - & 28 \\
\hline $\begin{array}{l}\text { Help in developing prototype solution, product or ready for product } \\
\text { testing }\end{array}$ & - & 22 \\
\hline $\begin{array}{l}\text { Help in negotiating and concluding contracts between the customer } \\
\text { and the technology provider }\end{array}$ & 18 & 22 \\
\hline Park did not implement this type of service in 2013 & - & 22 \\
\hline Searching for specific technologies according to companies orders & 27 & 17 \\
\hline Monitor technology implementation or contract implementation & 14 & 14 \\
\hline Evaluation of technology on behalf of companies & 9 & 14 \\
\hline Defining the transfer object & 32 & 11 \\
\hline Market tests of prototypes of products/services & - & 6 \\
\hline Certification of solutions/technology/products & - & 3 \\
\hline
\end{tabular}

Notes Adapted from Bąkowski and Mażewska (2015).

folio of technology parks in the United States and presented in the IASP report (table 5). However, the fact that the most popular service (assistance with contacting the supplier or technology user) is offered only in the $50 \%$ of surveyed parks may indicate that the offer of many entities is not adjusted to the needs of their tenants. The lack of availability of such activities means that the role of technology parks is often limited to the role of an office building. Another reason for this may be the lack of competence of technology park workers to provide specialized services. The solution should be to outsource some tasks to specialist businesses, or to attract companies that could provide services to other tenants.

In 2013 in technology parks in Poland 1,072 tenants were identified, compared to 656 in 2011 . This trend is positive, but only $50 \%$ of tenants 
are considered to be innovative companies. Within the group $25 \%$ are IT companies, the remaining $25 \%$ are professional, scientific and technical. $12.35 \%$ of companies operate in the trade, $17.2 \%$ in manufacturing, $3.97 \%$ in construction, and $16.3 \%$ other industries. Such a structure of tenants should be considered as unfavourable from the point of view of innovation policy assumptions, in which technology parks should support companies from highly regarded industries. The average annual budget of the technology park in 2013 was PLN 7.19m, and revenues are generated mainly from rental space (32.51\%). National and local grants are also very popular, accounting for around $36 \%$ of the park's budget, while in 2011 they accounted for approximately $53 \%$.

In the next few years, the budget structure should change as most parks in Poland are in a growth phase, so the budget should be more financed from rental space and additional services. The decline in the number of technology parks may be a result of the exhaustion of $\mathrm{EU}$ funds, while the remaining revenues are not enough for the current operation of the park and the repayment of loans. At present, the revenues from services and training are negligible, so in the next few years technology parks may be closed and converted into premium class offices.

\section{The Importance of Science and Technology Parks for the Development of New Modes of Cooperation in the Biopharmaceutical Industry}

Following the results of PWC study, any innovative pharmaceutical company participates on average in at least five projects aimed at building a coalition inside the industry. In Poland, we can find number of clusters and numerous science and technology parks (s T Ps) that offer the infrastructure for the development of innovative biotechnological and pharmaceutical products - in particular, the laboratory space. Science and technology parks (s T P s) also contribute to the development of biotechnology and pharmacy in Poland. ST PS promote the transfer of knowledge from universities to business (Staszków 2013). We can distinguish following clusters and stps operating in biopharma in Poland: Poznan Science and Technology Park, Nickel Technology Park Poznan, Wielkopolska BioRegion, Gdansk Science and Technology Park, Pomeranian Science and Technology Park, InnoBioBiz Lodz Cluster, BioTechMed Technology Centre, Lodz Technopark, Polish Technological Platform of Innovative Medicine, Biocentre Ochota Consortium, Nutribiomed Cluster, Wroclaw Research Centre EIT+, Wroclaw Technology Park, LifeScience Cluster 


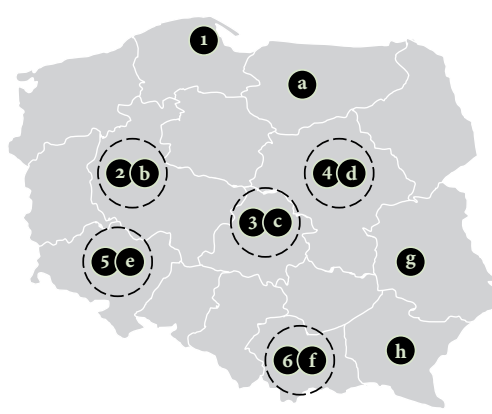

1. Gdańsk Science and Technology Park, Pomeranian Science and Technology Park

2. Poznan Science and Technology Park, Nickel Technology Park Poznan, Wielkopolska BioRegion

3. InnoBioBiz Łodź Cluster, BioTechMed Technology Centre, Łodź Technopark

4. Polish Technological Platform of Innovative Medicine, Biocentre Ochota Consortium

5. Nutribiomed Cluster, Wroclaw Research Centre EIT+, Wroclaw Technology Park

6. LifeScience Cluster Krakow, Jagiellonian Centre of Innovation

(a) Danisco Biolacta (b) GlaxoSmithKline

(c) Novartis, Nycomed

(d) DSM Nutritional Products, Bayer CropScience, Servier, Roche, Astra Zeneca, Krka

(e) Us Pharmacia, Sanitas, Maco Pharma

$\begin{array}{lll}\text { (f) Teva/Pliva (g) Baxter (h) Sanofi, Valeant } & \end{array}$

FIgURE 3 The Biggest FDI in the Pharmaceutical Industry and Location of Biopharmaceutical Clusters (letters) and st ps (numbers) and Possible Open Innovation Alliances (or A, dashed circles) in Poland (based on PAIIIZ 2012)

Krakow, Jagiellonian Centre of Innovation (Puślecki and Staszków 2015; Staszków 2013) (figure 4).

Taking into account the number of entities involved in Polish biopharmaceutical industry, especially pharmaceutical companies, s T Ps, universities and research institutes and clusters, it can be concluded that they can successfully apply the model of cooperation based on open innovation alliances.

\section{Conclusions}

Technological parks are differentiated in terms of age and ownership structure, and their names change depending on the country they are in. However, the merit of all park initiatives is the goals they should pursue. These are:

- Creation of a friendly environment supporting the development of innovation and entrepreneurship;

- Offering space for researchers and students to collaborate with business;

- Creation and development of knowledge-based enterprises through financial and management support;

- Creating new jobs and, as a result, contributing to increasing the well-being of the society.

Technological parks, as a tool of innovation policy of countries and regions, are to contribute to increasing the level of innovation, both at the local and national level. On the other hand, these are business entities 
that operate and compete on the market with other entities, and therefore equally important, though rarely mentioned, are economic objectives such as raising $\mathrm{EU}$ funds or making a profit. The specific objectives are conditioned by the stage in which the technological park is located. In the beginning phase, the most important issue is the raising of funds and the time and cost of building the park. Only in the later stage, in the growth and maturity phase the political objectives are gaining in importance - the development and incubation of new companies or the creation of jobs.

Examples of parks in the United States show that they are capable of meeting their statutory goals. The major source of success is the high involvement of universities in park development and management, which is not the case for Polish entities. Due to the public nature of the parks in the United States, the issue of profit seems to be less important, so the main goal is to implement the political and social assumptions. Polish parks are characterized by a diversified ownership structure, but their objectives should be consistent with regional innovation policy, so it is worthwhile to focus on building relationships and networking of the park among all its stakeholders, including regional innovation systems, research units, independent experts and financial institutions. As far as finances are concerned, Polish units focus mainly on local or EU funding, but in the longer run, it is necessary to balance the budget with rents and additional services. An element of great concern of American park managers is the industry profile of tenants. It is also an aspect that should be noted in Polish parks. However, in order to attract tenants with the right profile, parks need to increase the number of pro-innovation services actually provided. They should be provided not only to tenants, but also to external clients, which will help diversify the budget. Managers of American parks and academics stress the importance of defining a strategy for the development of a technology park, as well as the selection of managerial staff who will understand the specific function and objectives of technology parks.

Taking into account the above elements in the development of technology parks and regular evaluation of their effectiveness can contribute to the better functioning of parks in Poland. In result a successful cooperation with academia and science and technology parks will make it possible for biopharmaceutical companies in Poland to reduce the risks, costs of research (preserving and protecting intellectual property), and above all increase the likelihood of better therapeutic treatment for pa- 
tients, and to develop new modes of cooperation like open innovation alliances.

\section{Notes}

1 This paper includes findings from the research project financed by the research grant of the National Science Centre (Poland) awarded based on the decision no. DEC-2015/19/D/HS4/00414.

\section{References}

Allen, J., 2007. Third Generation Science Parks. Manchester: Manchester Science Park.

Almeida, A., C. Santos, and M. R. Silva. 2009. 'Bridging Science to Economy: The Role of Science and Technologic Parks in Innovation Strategies in "follower" regions.' Working paper, Universidade do Porto, ASAP - the Association of Strategic Alliance Professionals, Porto.

Asheim, B. T., and L. Coenen. 2005. 'Knowledge Bases and Regional Innovation Systems: Comparing Nordic Clusters.' Research Policy 34 (8): 1173-90.

Bąkowski, A., and M. Mażewska. 2015. Ośrodki innowacji i przedsiębiorczości $w$ Polsce: Raport 2014. Warsaw: Stowarzyszenie Organizatorów Ośrodków Innowacji i Przedsiębiorczości w Polsce.

Castells, P., and P. Hall. 1994. Technopoles of the World: The Making of the 21th Century Industrial Complexes. London: Routledge.

Felsenstein, D. 1994. 'University-Related Science Parks - "Seedbeds" or "Enclaves" of Innovation?' Technovation 14 (2): 93-110.

Henneberry, J. M. 1984. 'British and American Science Parks: A Comparison.' Property Management 2 (4): 301-13.

IASP. 2012. Science and Technology Parks Throughout the World: IASP General Survey 2012. Campanillas: IASP.

Link, A. N., 2009. 'Research, Science and Technology Parks: An Overview of the Academic Literature.' In Understanding Research, Science and Technology Parks: Global Best Practice; Report of a Symposium, edited by C. W. Wessner, 127-39. Washington, DC: The National Academies Press.

Link, A. N., and J. T. Scott. 2007. 'The Economics of University Research Parks.' Oxford Review of Economic Policy 23 (4): 661-74.

Matusiak, K. B., 2008. Innowacje i transfer technologii: stownik pojęć. Warsaw: PARP.

Matusiak, K. B., 2011. Strategiczne obszary rozwoju parków technologicznych. Warsaw: Polska Agencja Rozwoju Przedsiębiorczości.

Matusiak, K. B., A. Bąkowski. 2008. Wybrane aspekty funkcjonowania parków technologicznych $w$ Polsce i na świecie. Warsaw: PARP. 
PAIiIz. 2012. Sektor farmaceutyczny i biotechnologiczny w Polsce. Warsaw: paIiIz.

Pelle, D., M. Bober, and M. Lis. 20o8. Parki technologiczne jako instrument polityki wspierania innowacji dyfuzji wiedzy. Warsaw: Instytut Badań Strukturalnych.

Puślecki, Ł., and M. Staszków. 2015. 'New Cooperation Modes: An Opportunity for Polish Biotechnological Clusters.' Managing Global Transitions 13 (2): 171-88.

Staszków, M. 2013. 'Parki naukowo-technologiczne - miejsce wsparcia innowacyjnego biznesu.' Prace Naukowe Uniwersytetu Ekonomicznego we Wrocławiu, no. 315, 2:269-77.

'Ustawa z dn. 20 marca 2002 r. o finansowym wspieraniu inwestycji.' 2002. Dziennik Ustaw, no. 41.

Wessner, C., ed. 2009. Understanding Research, Science and Technology Parks: Global Best Practice, Report of a Symposium. Washington, DC: The National Academies Press.

World Bank. 2010. Innovation Policy: A Guide for Developing Countries. Washington, DC: The World Bank. 